\title{
Genetic relationship in goatfishes (Mullidae: Perciformes) of the Red Sea and the Mediterranean, with remarks on Suez Canal migrants*
}

\author{
D. GOLANI ${ }^{1}$ and U. RITTE ${ }^{2}$ \\ ${ }^{1}$ Department of Evolution, Systematics and Ecology, The Hebrew University of Jerusalem, 91904 Jerusalem, Israel. \\ ${ }^{2}$ Department of Genetics, The Hebrew University of Jerusalem, 91904 Jerusalem, Israel
}

\begin{abstract}
SUMMARY: An electrophoretic examination of 21 presumptive loci was used to analyze the genetic relationship in the fish family Mullidae. The present study included seven species from the Red Sea and two from the Mediterranean. Two of the Red Sea species (Upeneus pori and U. moluccensis), which had colonized the Mediterranean via the Suez Canal, were also sampled in their new habitat. The electrophoretic results support the taxonomy which is based on morphomeristic measurements, with the exception of $U$. pori, the genetic distance of which with its congeneric species is at a level which is attributed to different genera. No discernible genetic difference was found between the populations of the colonizing species in both seas $(\mathrm{D}=0.004$ for $U$. moluccensis, $\mathrm{D}=0.081$ for $U$. pori $)$, as well as between colonizing and non-colonizing species. The average heterozygosity of Mullidae is lower than the average known for other fishes.
\end{abstract}

Key words: Mullidae, genetic relationship, Red Sea, eastern Mediterranean, migration.

\section{INTRODUCTION}

The goatfish family (Mullidae) can be easily distinguished from all other percoids by their unique hyoid barbels, used in trophic foraging. This circumtropical family includes about 50 species belonging to six genera.

Most goatfish inhabit inshore areas and are commercially important throughout their distribution. Due to their economic value, goatfish have been the subject of rather intense biological and taxonomic studies (e.g., Lee, 1974; Munro, 1976; Papaconstantinou et al., 1981; Sorden, 1983; Gosline, 1984; Wahbeh, 1992a,b; Golani, 1994).

\footnotetext{
*Received July 13, 1998. Accepted February 2, 1999.
}

The taxonomy of Mullidae in the Red Sea has received considerable attention (Dor and Ben-Tuvia, 1984; Al-Absey, 1988; Ben-Tuvia and Kissil, 1988). Thirteen species have been reported from the Red Sea region, belonging to three genera: Mulloides Bleeker, 1849, Parupeneus Bleeker, 1863 and Upeneus Cuvier, 1829. Electrophoretic analysis can add a different dimension, which provides insight into the interrelationship of species and genera, to these taxonomic studies (Avise, 1974; Buth, 1984; Bolch et al., 1994). Regarding the Red Sea Mullidae, electrophoretic studies may be of particular interest, since two members of this family, the brownband goatfish Upeneus pori Ben-Tuvia and Golani, 1989 (previously known in this area as $U$. asymmetricus), and the goldband goatfish, Upeneus 
moluccensis (Bleeker, 1855), have migrated through the Suez Canal, which was opened in 1869, into the Mediterranean Sea. Colonization exposed these populations to ecological pressures that may have differed from those exerted on their original populations. Therefore, it has been hypothesized that the colonizing population would undergo some changes (Parsons, 1984). Despite the different hydrological conditions and faunistic affinities of these two seas, each of these two species succeeded to establish a large permanent population in the Mediterranean. In their new region they encountered two indigenous mullids, the red mullet Mullus barbatus Linneaus, 1758, and the striped mullet, Mullus surmuletus Linneaus, 1758 .

Another question presented by Lessepsian migration is the association between genetic variability and success in colonization. High genetic variability has been hypothesized as a preadaptation to a heterogeneous environment (Hedrick et al., 1976). Since successful colonization often requires the occupation of new and different habitats, it is expected that successful colonizer species have high genetic variability (Baker and Stebbins, 1965; Safriel and Ritte, 1980; Gray, 1986; Williamson and Fitter, 1996).

The purpose of this study is thus threefold: to determine the genetic relationship between Red Sea mullid species and their Mediterranean confamilials; to compare the genetic structure of Red Sea and Mediterranean populations of the colonizing species; and to compare the genetic structure of colonizing and non-colonizing species.

\section{MATERIALS AND METHODS}

\section{Collection of material}

Of the 13 known species of Red Sea Mullidae, 11 reach the Gulf of Elat (Ben-Tuvia and Kissil, 1988). Seven species, representing all three genera that occur in this region, were sampled for the present study. Five of these species, Mulloides flavolineatus (Lacepède, 1801), Parupeneus macronema (Lacepède, 1801), P. rubescens (Lacepède, 1801), Upeneus moluccensis (Bleeker, 1855) and U. subvittatus (Temminck and Schlegel, 1843), have a wide zoogeographic distribution, including the Indian Ocean and the western Pacific. The two other species, Parupeneus forsskali Fourmanoir and Guézé, 1976 and Upeneus pori Ben-Tuvia and Golani, 1989 were considered endemic to the Red Sea until the latter extended its distribution into the Mediterranean. Of the three species that were not sampled, two, namely Mulloides vanicolensis Valenciennes, 1831 and Parupeneus heptacanthus (Lacepède, 1801), are rare in the northern part of the Gulf of Elat and never appeared in our catches. The third species, Parupeneus cyclostomus (Lacepède, 1801 ), is associated with coral reefs in which collection is prohibited by law.

TABLE 1. - Number of individuals, length range, date, method of capture and catalogue numbers.

\begin{tabular}{|c|c|c|c|c|c|}
\hline & $\begin{array}{l}\text { number of } \\
\text { individuals }\end{array}$ & $\begin{array}{l}\text { total } \\
\text { length } \\
(\mathrm{mm})\end{array}$ & date & $\begin{array}{l}\text { method of } \\
\text { capture }\end{array}$ & $\begin{array}{r}\text { HUJ } \\
\text { catalogue } \\
\text { number* }\end{array}$ \\
\hline \multicolumn{6}{|l|}{ RED SEA } \\
\hline $\begin{array}{l}\text { Upeneus pori } \\
\text { “" } \\
\text { U. moluccensis } \\
\text { U. subvittatus } \\
\text { “" } \\
\text { Mulloides flavolineatus } \\
\text { Parupeneus forsskali } \\
\text { “" } \\
\text { P. rubescens } \\
\text { P. macronema }\end{array}$ & $\begin{array}{r}20 \\
30 \\
16 \\
1 \\
4 \\
48 \\
23 \\
17 \\
40 \\
6\end{array}$ & $\begin{array}{c}100-162 \\
116-149 \\
99-131 \\
149 \\
119-212 \\
138-173 \\
51-86 \\
171-257 \\
76-130 \\
111-182\end{array}$ & $\begin{array}{l}\text { Mar. } 30,86 \\
\text { June 21, 86 } \\
\text { Dec. } 6,86 \\
\text { Apr. } 30,86 \\
\text { Nov. } 12,86 \\
\text { Nov. } 30,86 \\
\text { Nov. } 8,86 \\
\text { Nov. } 15,86 \\
\text { June } 21,86 \\
\text { Nov. } 15,86\end{array}$ & $\begin{array}{c}\text { Beach seine } \\
\text { “ } \\
\text { Trammel net } \\
\text { “ “ “ } \\
\text { Beach seine } \\
\text { “ “ } \\
\text { Spear gun } \\
\text { Beach seine } \\
\text { Spear gun }\end{array}$ & $\begin{array}{l}13598 \\
13599 \\
13600 \\
13601 \\
13602 \\
13603 \\
13604 \\
13605 \\
13606 \\
13607\end{array}$ \\
\hline \multicolumn{6}{|l|}{ MEDITERRANEAN } \\
\hline $\begin{array}{l}\text { Upeneus pori } \\
\text { U. moluccensis } \\
\text { Mullus barbatus } \\
\text { M. surmuletus }\end{array}$ & $\begin{array}{l}50 \\
38 \\
38 \\
14\end{array}$ & $\begin{array}{c}93-153 \\
102-175 \\
105-202 \\
120-205\end{array}$ & $\begin{array}{l}\text { May 4, } 86 \\
\text { May 4,86 } \\
\text { May 5, 86 } \\
\text { May 5, } 86\end{array}$ & $\begin{array}{c}\text { Trawl } \\
\text { “ } \\
“ \\
\text { “ }\end{array}$ & $\begin{array}{l}13608 \\
13609 \\
13610 \\
13611\end{array}$ \\
\hline
\end{tabular}

*All studied fish are deposited in the Hebrew University Fish Collection (HUJ). 
TABLE 2. - The different enzymes (including the tissue from which each was extracted, and the buffer system that was used for its analysis) that were analyzed in the present study.

\begin{tabular}{|c|c|c|c|c|}
\hline enzyme & $\begin{array}{l}\text { E.C. } \\
\text { number }\end{array}$ & $\begin{array}{l}\text { abbrevi- } \\
\text { ations }\end{array}$ & tissue* & $\begin{array}{c}\text { buffer } \\
\text { system** }\end{array}$ \\
\hline Adenosine deaminase & 3.5 .4 .4 & $\mathrm{ADA}$ & $\mathrm{L}$ & 1 \\
\hline Alkaline phosphatase & 3.1.3.4 & ALP & $\mathrm{L}$ & 2 \\
\hline Amino peptidase & 3.4 .1 .2 & AP-1 & $\mathrm{L}$ & 1 \\
\hline Amino peptidase & 3.4 .1 .2 & AP-2 & $\mathrm{L}$ & 1 \\
\hline Esterase & 3.1 .1 .1 & EST & $\mathrm{L}$ & 3 \\
\hline General Protein & - & Gen-Prot-1 & M & 3 \\
\hline 6 & & Gen-Prot-2 & M & 3 \\
\hline “ & & Gen-Prot-3 & M & 3 \\
\hline “ & & Gen-Prot-4 & M & 3 \\
\hline “ & & Gen-Prot-5 & M & 3 \\
\hline Glycerate dehydrogenase & $1 . \overline{1.1} .29$ & GlyDH & M & 3 \\
\hline \multicolumn{5}{|c|}{ Glucose-6-phosphate } \\
\hline dehydrogenase & 1.1.1.46 & G6PD-1 & $\mathrm{L}$ & 2 \\
\hline 64 & 1.1.1.46 & G6PD-2 & $\mathrm{L}$ & 2 \\
\hline Glucokinase & 2.7 .1 .2 & GK & $\mathrm{L}$ & 2 \\
\hline Isocitrate dehydrogenase & 1.1 .1 .42 & IDH & $\mathrm{L}+\mathrm{M}$ & 3 \\
\hline Malic enzyme & 1.1.1.40 & ME-1 & $\mathrm{L}+\mathrm{M}$ & 3 \\
\hline 64 & 1.1.1.40 & ME-1 & $\mathrm{L}+\mathrm{M}$ & 3 \\
\hline \multicolumn{5}{|l|}{ 6-Phosphogluconate } \\
\hline dehydrogenase & 1.1.1.44 & PGD & $\mathrm{L}$ & 2 \\
\hline Phosphoglucomutase & 2.7 .5 .1 & PGM-1 & $\mathrm{L}$ & 2 \\
\hline 16 & 2.7.5.1 & PGM-2 & $\mathrm{L}$ & 2 \\
\hline Xanthine dehydrogenase & 1.2 .3 .2 & $\mathrm{XDH}$ & $\mathrm{L}+\mathrm{M}$ & 3 \\
\hline
\end{tabular}

* L - liver; $\mathrm{M}$ - muscle

** 1 - Tris-Citrate pH 6.7/6.3, $4.7 \mathrm{Cm} / \mathrm{V}, 6-7 \mathrm{~h}$

2 - Tris-Citrate $\mathrm{pH}$ 8.0, 2.7-3.3 Cm/V, 6-7 h

3 - Lithium Hydroxide $\mathrm{pH} 8.1 / 8.4,7.3-12.7 \mathrm{Cm} / \mathrm{V}, 6-7 \mathrm{~h}$

In the eastern Mediterranean, populations of the two migrants, Upeneus moluccensis and U. pori, were sampled, as well as the two indigenous goatfish Mullus barbatus and M. surmuletus which extend to the northeastern Atlantic.

Fish collection was conducted in the northern tip of the Red Sea (Gulf of Elat) and the eastern Mediterranean. Details of the collection are presented in Table 1. Fishes collected by beach seine and trawl were placed on dry ice immediately upon capture. Those captured by trammel nets and spear guns were placed on dry ice no later than 45 minutes after capture. Fish were delivered frozen to the Department of Genetics at the Hebrew University and stored at $-40^{\circ} \mathrm{C}$.

\section{Electrophoresis}

Muscle and liver tissue were dissected from each individual and homogenized with equal volumes of 0.1 M Tris-HC1 pH 7.0: $\mathrm{H}_{2} \mathrm{O}$ : Glycerol (2:2:1) using a Sonifier Cell Disruptor, model W185 (Heat System-Ultrasonic, Inc.) $(10,000 \mathrm{rpm})$. The homogenates were centrifuged at $4^{\circ} \mathrm{C}$ for $30 \mathrm{~min}$ at $14,000 \mathrm{~g}$. The supernatants were run on horizontal starch gels using $12 \%$ hydrolyzed starch (Sigma No. S-4501) at $4^{\circ} \mathrm{C}$.

The enzymes analyzed are listed in Table 2. Staining procedures followed Selander et al. (1971) and Harris and Hopkinson (1976). Enzyme nomenclature followed the International Union of Biochemistry recommendations. Allelic designations were determined according to their electrophoretic mobility, following Buth (1983).

\section{Genetic analysis}

The genetic distances between all possible pairs were calculated using Nei's (1978) index. The DISPAN computer program (Ota, 1993), using the neighbour-joining method (Saitou and Nei, 1987), was based on genetic distances and applied in the construction of an unrooted phylogenetic tree. This program was chosen because it allows compensation for possible bias due to a small number of individuals in sample size; a few species in this study were represented by less than 20 individuals. Allele frequencies of the different enzymes were used for the calculation of the levels of polymorphism $(\overline{\mathrm{P}})$ and heterozygosity $(\overline{\mathrm{H}})$ for each species.

\section{RESULTS}

Gene products of 21 loci were screened. Their allele frequencies are given in Table 3. Because six loci (ADA, ALP, Gen Prot-1, ME-1, ME-2 and $\mathrm{XDH}$ ) were monomorphic for the same allele in all species, they are not included in Table 3. Five other loci (G6PD-1, Gen Prot-3, Gen Prot-4, IDH and PGD) were also monomorphic, but not all species were monomorphic for the same allele. Ten loci (AP-1, AP-2, EST, Gen Prot-2, Gen Prot-5, G6PD2, GlyDH, Gk, PGM-1 and PGH-2) were polymorphic in at least one species (Table 3).

The genetic distances (Nei, 1978) between all species and populations are given in Table 4 . The neighbour-joining phylogenetic tree constructed by the DISPAN program is given in Fig 1. The mean levels of polymorphism and heterozygosity are listed in Table 5.

Mean polymorphism in Red Sea and Mediterranean Sea goatfish $(\overline{\mathrm{P}}=0.108 \pm 0.028)$ was significantly lower than the value $(\overline{\mathrm{P}}=0.209 \pm 0.137)$ found for 200 species of fishes (Nevo et al., 1984), $(\mathrm{t}=7.692$ (209 d.f.); $\mathrm{p}<0.001)$, but slightly higher than the value $(\overline{\mathrm{P}}=0.064)$ found for goatfish from 
TABLE 3. - Allele frequencies in Red Sea and Mediterranean goatfishes. U.p. = Upeneus pori, U.m. $=$ U. moluccensis, U.s. $=$ U. subvittatus, M.f. = Mulloides flavolineatus, P.f. = Parupeneus forsskali. P.r. = P. rubescens, P.m. = P. macronema, M.b. = Mullus barbatus, M.s $=$ M. surmuletus. $(\mathrm{M})=$ Mediterranean, $(\mathrm{R})=$ Red Sea. (Sample size is given next to species name; exceptions are indicated in the body of the table)

\begin{tabular}{|c|c|c|c|c|c|c|c|c|c|c|c|c|}
\hline Locus & allele & $\begin{array}{c}\text { U.p } \\
\text { (M) } \\
n=50\end{array}$ & $\begin{array}{c}\text { U.p. } \\
\text { (R) } \\
\mathrm{n}=50\end{array}$ & $\begin{array}{c}\text { U.m. } \\
\text { (M) } \\
\mathrm{n}=38\end{array}$ & $\begin{array}{c}\text { U.m. } \\
\text { (R) } \\
\mathrm{n}=16\end{array}$ & $\begin{array}{l}\text { U.s. } \\
n=5\end{array}$ & $\begin{array}{l}\text { M.f. } \\
\mathrm{n}=48\end{array}$ & $\begin{array}{c}\text { P.f. } \\
n=40\end{array}$ & $\begin{array}{c}\text { P.r. } \\
\mathrm{n}=40\end{array}$ & $\begin{array}{l}\text { P.m. } \\
n=6\end{array}$ & $\begin{array}{l}\text { M.b. } \\
\mathrm{n}=38\end{array}$ & $\begin{array}{l}\text { M.s. } \\
\mathrm{n}=14\end{array}$ \\
\hline AP-1 & $\begin{array}{l}\text { A } \\
\text { B }\end{array}$ & 1.000 & 1.000 & 1.000 & 1.000 & 1.000 & 1.000 & 1.000 & 1.000 & $\begin{array}{l}0.083 \\
0.917\end{array}$ & 1.000 & 1.000 \\
\hline AP-2 & $\begin{array}{l}\text { A } \\
B \\
C \\
D\end{array}$ & $\begin{array}{l}0.970 \\
0.030\end{array}$ & $\begin{array}{l}0.990 \\
0.010\end{array}$ & 1.000 & 1.000 & 1.000 & 1.000 & 1.000 & 1.000 & 1.000 & 1.000 & 1.000 \\
\hline EST & $\begin{array}{l}\text { A } \\
\text { B }\end{array}$ & $\begin{array}{l}0.970 \\
0.030\end{array}$ & $\begin{array}{l}0.670 \\
0.330\end{array}$ & $\begin{array}{l}0.868 \\
0.132\end{array}$ & $\begin{array}{l}0.531 \\
0.469\end{array}$ & 1.000 & $\begin{array}{l}0.094 \\
0.906\end{array}$ & $\begin{array}{l}0.357 \\
0.643\end{array}$ & $\begin{array}{l}0.888 \\
0.112\end{array}$ & 1.000 & $\begin{array}{l}0.526 \\
0.474\end{array}$ & $\begin{array}{l}0.321 \\
0.679\end{array}$ \\
\hline Gen Prot-2 & $\begin{array}{l}\text { A } \\
\text { B } \\
\text { C } \\
\text { D }\end{array}$ & $\begin{array}{l}0.040 \\
0.960\end{array}$ & 1.000 & 1.000 & 1.000 & 1.000 & 1.000 & 1.000 & $\begin{array}{l}0.950 \\
0.050\end{array}$ & 1.000 & 1.000 & 1.000 \\
\hline Gen Prot-3 & $\begin{array}{l}\text { A } \\
\text { B }\end{array}$ & 1.000 & 1.000 & 1.000 & 1.000 & 1.000 & 1.000 & 1.000 & 1.000 & 1.000 & 1.000 & 1.000 \\
\hline Gen Prot-4 & & 1.000 & 1.000 & 1.000 & 1.000 & & & & & & & \\
\hline Gen Prot-5 & $\begin{array}{l}\mathrm{A} \\
\mathrm{B} \\
\mathrm{C}\end{array}$ & 1.000 & 1.000 & 1.000 & 1.000 & $\begin{array}{l}0.900 \\
0.100\end{array}$ & 1.000 & 1.000 & 1.000 & 1.000 & 1.000 & 1.000 \\
\hline GlyDH & $\begin{array}{l}\mathrm{A} \\
\mathrm{B} \\
\mathrm{C}\end{array}$ & $\begin{array}{l}0.020 \\
0.980\end{array}$ & $\begin{array}{l}0.020 \\
0.980\end{array}$ & 1.000 & 1.000 & 1.000 & 1.000 & 1.000 & 1.000 & 1.000 & 1.000 & $\begin{array}{l}0.536 \\
0.464\end{array}$ \\
\hline G6PD-1 & $\begin{array}{l}\text { A } \\
\text { B }\end{array}$ & 1.000 & 1.000 & 1.000 & 1.000 & 1.000 & 1.000 & 1.000 & 1.000 & 1.000 & 1.000 & 1.000 \\
\hline G6PD-2 & $\begin{array}{l}\mathrm{A} \\
\mathrm{B} \\
\mathrm{C}\end{array}$ & & & $\begin{array}{l}\mathrm{n}=22 \\
1.000\end{array}$ & 1.000 & 1.000 & & 1.000 & $\begin{array}{l}0.851 \\
0.149\end{array}$ & 1.000 & 1.000 & 1.000 \\
\hline GK & $\begin{array}{l}\text { A } \\
\text { B } \\
\text { C }\end{array}$ & $\begin{array}{l}0.070 \\
0.930\end{array}$ & $\begin{array}{l}0.090 \\
0.910\end{array}$ & 1.000 & 1.000 & 1.000 & 1.000 & 1.000 & 1.000 & 1.000 & 1.000 & 1.000 \\
\hline IDH & $\begin{array}{l}\text { A } \\
\text { B }\end{array}$ & 1.000 & 1.000 & 1.000 & 1.000 & 1.000 & 1.000 & 1.000 & 1.000 & 1.000 & 1.000 & 1.000 \\
\hline PGD & $\begin{array}{l}\text { A } \\
B \\
\text { C } \\
\text { D }\end{array}$ & 1.000 & 1.000 & 1.000 & 1.000 & 1.000 & 1.000 & 1.000 & 1.000 & 1.000 & 1.000 & 1.000 \\
\hline PGM-1 & $\begin{array}{l}\text { A } \\
\text { B } \\
\text { C }\end{array}$ & $\begin{array}{l}\mathrm{n}=21 \\
0.313 \\
0.687\end{array}$ & $\begin{array}{l}\mathrm{n}=24 \\
1.000\end{array}$ & $\begin{array}{l}\mathrm{n}=24 \\
0.500 \\
0.500\end{array}$ & $\begin{array}{l}0.406 \\
0.594\end{array}$ & $\begin{array}{l}0.500 \\
0.500\end{array}$ & $\mathrm{n}=24$ & $\begin{array}{l}0.525 \\
0.475\end{array}$ & $\begin{array}{l}0.063 \\
0.937\end{array}$ & $\begin{array}{l}0.500 \\
0.500\end{array}$ & $\begin{array}{l}\mathrm{n}=30 \\
0.500 \\
0.500\end{array}$ & $\begin{array}{l}0.536 \\
0.464\end{array}$ \\
\hline PGM-2 & $\begin{array}{l}\text { A } \\
\text { B } \\
\text { C } \\
\text { D }\end{array}$ & 1.000 & 1.000 & 1.000 & 1.000 & 1.000 & 1.000 & 1.000 & 1.000 & 1.000 & $\begin{array}{l}0.960 \\
0.040\end{array}$ & 1.000 \\
\hline
\end{tabular}

Hawaii (Shaklee et al., 1982). The average heterozygosity of Red Sea and Mediterranean goatfishes $(\overline{\mathrm{H}}=0.042 \pm 0.018)$ was also lower but not significantly different from the value $(\overline{\mathrm{H}}=0.051 \pm$ $0.035)$ found by Nevo et al. (1984) for 183 species of fishes ( $t=1.507$ (192 d.f.); $p>0.100)$.

For each of the two migrating species, Upeneus pori and U. moluccensis, the level of genetic differ- entiation between the Mediterranean and the Red Sea populations was estimated using both the twotailed Fisher's exact test for independence and Wright's $F_{\mathrm{ST}}$ statistic. Since each polymorphic locus has only two alleles, and for each species we compare only two populations, we preferred to use the exact test over the more commonly used $\chi^{2}$ test for independence. The significance of departure of $F_{\text {ST }}$ 
TABLE 4. - Standard genetic distances (Nei, 1978) among Red Sea and Mediterranean goatfishes (Abbreviations as in Table 3).

\begin{tabular}{|c|c|c|c|c|c|c|c|c|c|c|}
\hline & $\begin{array}{l}\text { U.p. } \\
\text { (M) }\end{array}$ & $\begin{array}{l}\text { U.p. } \\
\text { (R) }\end{array}$ & $\begin{array}{l}\text { U.m. } \\
\text { (M) }\end{array}$ & $\begin{array}{l}\text { U.m. } \\
\text { (R) }\end{array}$ & U.S. & M.f. & P.f. & P.r. & P.m. & M.b. \\
\hline U.p.(R) & 0.081 & & & & & & & & & \\
\hline U.m.(M) & 0.383 & 0.512 & & & & & & & & \\
\hline U.m.(R) & 0.395 & 0.515 & 0.004 & & & & & & & \\
\hline U.s. & 0.239 & 0.357 & 0.106 & 0.118 & & & & & & \\
\hline M.f. & 0.431 & 0.557 & 0.602 & 0.561 & 0.428 & & & & & \\
\hline P.f. & 0.682 & 0.819 & 0.475 & 0.460 & 0.476 & 0.474 & & & & \\
\hline P.r & 0.618 & 0.804 & 0.461 & 0.469 & 0.451 & 0.336 & 0.199 & & & \\
\hline P.m & 0.609 & 0.714 & 0.414 & 0.380 & 0.422 & 0.382 & 0.114 & 0.104 & & \\
\hline M.b. & 0.477 & 0.509 & 0.461 & 0.456 & 0.470 & 0.483 & 0.458 & 0.250 & 0.319 & \\
\hline M.s. & 0.380 & 0.424 & 0.437 & 0.424 & 0.373 & 0.378 & 0.879 & 0.245 & 0.268 & 0.079 \\
\hline
\end{tabular}

TABLE 5. - Number of analyzed loci, number of polymorphic loci, mean polymorphism and mean heterozygosity in Red Sea and Mediterranean goatfishes (numbers in parentheses indicate alleles which had frequencies of less than 5\%).

\begin{tabular}{lccccc}
\hline & $\begin{array}{c}\text { No. of } \\
\text { loci }\end{array}$ & $\begin{array}{c}\text { No. of } \\
\text { Polymorphic loci }\end{array}$ & $\begin{array}{c}\text { mean } \\
\text { polymorphism }\end{array}$ & $\begin{array}{c}\text { mean } \\
\text { heterozygosity }\end{array}$ & $\begin{array}{c}\text { Heterozygosity } \\
\text { S.E. }\end{array}$ \\
\hline $\begin{array}{l}\text { Upeneus pori (Medit.) } \\
\text { U. pori (R.S.) }\end{array}$ & 20 & $3(3)$ & 0.150 & 0.0411 & 0.0231 \\
U. moluccensis (Medit.) & 20 & $2(2)$ & 0.100 & 0.0339 & 0.0235 \\
U. moluccensis (R.S.) & 21 & 2 & 0.095 & 0.0378 & 0.0280 \\
U. subvittatus & 21 & 2 & 0.095 & 0.0517 & 0.0356 \\
Mulloides flavolineatus & 20 & 1 & 0.053 & 0.0425 & 0.0087 \\
Parupenus forsskali & 19 & 2 & 0.100 & 0.0491 & 0.0338 \\
P. rubescens & 20 & 2 & 0.143 & 0.0211 & 0.0122 \\
P. macronema & 20 & $2(1)$ & 0.100 & 0.0391 & 0.0554 \\
Mullus barbatus & 20 & 3 & 0.150 & 0.0770 & 0.0353 \\
M. surmuletus & 20 & & & & \\
\hline
\end{tabular}

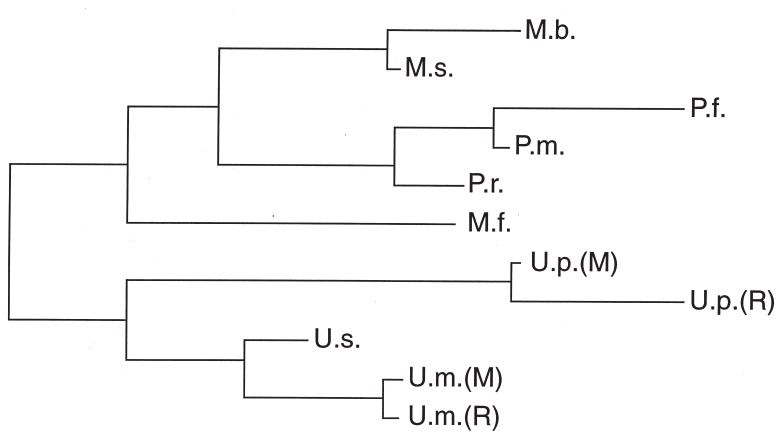

FIG. 1. - A neighbour-joining phylogenetic dendrogram of the standard genetic distances analyzed for the Red Sea and Mediterranean mullid. (Abbreviations as in Table 3).

values from zero was calculated using the $\chi^{2}$ test of Workman and Niswander (1970).

The effective number of migrants per population per generation $\left(N_{e} m\right)$ can be obtained from the $F_{\mathrm{ST}}$ statistic by the formula:

$$
N_{e} m=-\frac{1-F_{S T}}{4 F_{S T}} \quad \text { (Walpes, 1987). }
$$

TABLE 6. - Level of genetic differentiation between Red Sea and Mediterranean populations of the colonizing goatfishes.

\begin{tabular}{lllll}
\hline Species & Locus & $\begin{array}{r}\text { No. of } \\
\text { alleles }\end{array}$ & $\begin{array}{c}\text { Fisher's } \\
\text { Exact Test }\end{array}$ & $\mathrm{F}_{\text {st }}$ \\
\hline Upeneus pori & & & & \\
& AP-2 & 2 & $\mathrm{P}=0.3712$ & $0.0051(\mathrm{NS})$ \\
& EST & 2 & $\mathrm{P}=8.31 \times 10^{-9}$ & $0.1524(* *)$ \\
& Pen Prot 2 & 2 & $\mathrm{P}=0.0606$ & $0.0204(*)$ \\
& GlyDH & 2 & $\mathrm{P}=1.0000$ & $0(\mathrm{NS})$ \\
& GK & 2 & $\mathrm{P}=0.6152$ & $0.0014(\mathrm{NS})$ \\
& PGM-1 & 2 & $\mathrm{P}=7.71 \times 10^{-14}$ & $0.5232(* *)$ \\
Upeneus moluccensis & EST & 2 & $\mathrm{P}=3.31 \times 10^{-4}$ & $0.1351(* *)$ \\
& PGM-1 & 2 & $\mathrm{P}=0.4946$ & $0.0089(\mathrm{NS})$ \\
& & & & \\
\hline
\end{tabular}

NS = not significant; $(*)=\mathrm{p}<0.05 ;(* *)=\mathrm{p}<0.01$

The results of the tests of the level of genetic differentiation in Upeneus pori and U. moluccensis are given in Table 6. For $U$. pori, the mean $F_{\mathrm{ST}}$ over all six polymorphic loci was 0.1171 .

The effective number of migrants between populations is estimated as 1.89 individuals per generation. For $U$. moluccensis, the mean $F_{\mathrm{ST}}$ over the two polymorphic loci was 0.0720 . The effective number of migrants between populations is estimated as 3.22 individuals per generation. 
Average heterozygosity for the Red Sea populations of the migrating species, for both $U$. pori and U. moluccensis, was $0.04283(\mathrm{n}=2)$, while the average heterozygosity for the non-migrating Red Sea species (e.g., Upeneus subvittatus, Mulloides flavolineatus, Parupeneus forsskali, $P$. rubescens and $P$. macronema) was $0.03212(\mathrm{n}=5)$. This difference is statistically not significant $(\mathrm{t}=0.8022$ (5 d.f.); $\mathrm{p}>0.400$ ).

\section{DISCUSSION}

The electrophoretic analysis of the Red Sea and Mediterranean goatfish generally supports the conclusions of the morphomeristic-based systematic studies of this family (Al-Absey, 1988; Ben-Tuvia and Kissil, 1988).

The only notable exception is $U$.pori, which clusters to its other congeneric species at a level which has been found in this study to distinguish between genera. This finding supports Kühlmorgen-Hille (1974), who suggested to split Upeneus into two subgenera; Upeneus (Upeneus) for species with five to seven interdorsal fin scales and 12 rows on the upper part of the peduncle (including $U$. moluccensis and U. subvittatus), and Upeneus (Penon) for species with four interdorsal fin scales and ten scale rows on the peduncle (including U. pori).

The interrelationship between genera found in this study agrees with that of Shaklee et al. (1982), who found that Upeneus clusters first with Mulloidichthys (= Mulloides) and later with Parupeneus.

The morphological similarity between Mullus barbatus and $M$. surmuletus has led some authors (Day, 1880-84; Lozano Ray, 1952) to treat them as different subspecies. Despite the results of our electrophoretic analysis which also found them to be very close, we refrain from drawing a categorical conclusion, especially in light of Basaglia and Callegarini (1988) and Mamuris et al. (1998), who also used electrophoresis and clearly distinguished these two fish as belonging to two separate species.

It has been speculated that the Red Sea fishes, found today in the Mediterranean, inhabited it prior to the opening of the Suez Canal. Unfortunately, before that event, little was known on the ichthyofauna of the eastern Mediterranean. However, due to their Atlantic origin, almost all indigenous fishes from the eastern Mediterranean are also known from the western Mediterranean. The occurrence of Red Sea fishes with Indo-Pacific distribution exclusively in the eastern Mediterranean supports the interpretation of their recent arrival by migration through the Suez Canal. Early comparative studies of Lessepsian goatfishes in the Red Sea and the Mediterranean revealed some meristic changes, which were attributed to the adjustment of the spawning season to a more fluctuating temperature regime in the Mediterranean (Golani, 1990). The present electrophoretic study revealed a low level of genetic distance between the Red Sea and Mediterranean populations of the two colonizing species, U. pori $(\mathrm{D}=$ 0.081 ) and $U$. moluccensis $(\mathrm{D}=0.004)$. These values are lower than those calculated in Mullidae (Stepien et al., 1994) in particular, and among conspecific populations in general (Avise, 1974; Buth, 1984). Thus, it can be concluded that the short time elapsed since the establishment of the Mediterranean populations has not been sufficient to establish discernible genetic differences. Only a single allele (PGM-1-C) detected in the Mediterranean population of $U$. pori was not found in the Red Sea (Table 3). Because of the short time since the separation, it is reasonable to assume that this allele may also occur, perhaps rarely, in the Red Sea. The low level of genetic distance and the calculated effective number of migrants between the colonizing and the source populations (1.89 for $U$. pori and 3.22 for $U$. moluccensis) indicate that the establishment of the Mediterranean populations probably involved relatively large propagules and/or continuous gene flow from the Red Sea.

Our results concerning the question, whether high genetic variability contributes to success in colonization, are negative. This conclusion was reached by many other authors (Ritte and Pashtan, 1982; Ehrlich, 1986; Holdgate, 1986; Gray, 1986; Lavee and Ritte, 1994; Williamson and Fitter, 1996). The distinction between closely-related colonizing and non-colonizing species seems rather to be associated with ecological differences (Ayal and Safriel, 1983; Golani, 1993).

\section{ACKNOWLEDGEMENTS}

We thank Prof. A. Ben-Tuvia for his encouragement and discussion of Mullidae taxonomy, E. Neufeld for her contribution to the electrophoretic analysis, Prof. U. Motro and Dr E. Geffen for their help with the statistics, Ms. Chen Su and Dr. T. Ota for the supply of the DISPAN program, Dr. J.E. Randall for collecting some of the specimens in Elat, the 
crew of F/V Ophir for help in the collection of fish from the Mediterranean and Ms. B. Appelbaum for editorial assistance. This study was partly supported by the Lerner-Gray Fund for Marine Research, American Museum of Natural History, New York.

\section{REFERENCES}

Al-Absey, A.H. - 1988. Review of the goatfishes (Pisces; Perciformes: Mullidae) in the Gulf of Aqaba, Red Sea. In: W. Buttiker, and F. Krupp (eds.), Fauna of Saudi Arabia, Vol. 9, pp. 152 168. Nat. Comm. Wildl. Conserv. Develop. (NCWCD) Riyadh, Saudi Arabia.

Ayal, Y. and U. N. Safriel. - 1983. Does a suitable habitat guarantee successful colonization? J. Biogeog., 10: 37-41.

Avise, J.C. - 1974. Systematic value of electrophoretic data. Syst. Zool., 23: 465-481.

Baker, H.G. and G.L. Stebbins, (eds.). - 1965. The Genetics of Colonizing Species. Academic Press. New York; 588. pp.

Basaglia, F. and C. Callegarini. - 1988. Biochemical characteristics of red mullet of the central Mediterranean. Comp. Biochem. Physiol., 89 B: 731-736.

Ben-Tuvia, A. and G.W. Kissil. - 1988. Fishes of the family Mullidae in the Red Sea with a key to the Red Sea and the Mediterranean species. Ichthyol. Bull. J.L.B. Smith Institute. Spec. Publ., 51:1-16.

Bolch, C.J.S., D.R. Word, D.R. and P.R. Last. - 1994. Biochemical systematics of the marine family Centrolophidae (Teleostei: Stromateoidei) from Australian waters. Austr. J. Mar. Freshwater Res., 45: 1159-1172.

Buth, D.G. - 1983. Duplicate isozyme loci in fishes: Origins, distribution, phyletic consequences and locus nomenclature. In: M.C. Ratazzi, J.V.C. Scandalios and G.S. Whitt (eds.), Isozymes: Current Topics in Biological and Medical Research. Vol. 10, pp. 381-400. Alan R. Liss, New York.

Buth, D.G. - 1984. The application of electrophoretic data in systematic studies. Ann. Rev. Ecol. System., 15:501-522.

Day, F. - 1880-1884. The Fishes of Great Britain and Ireland. London-Edinburgh; 336 + CXII. Pp.

Dor, M. and A. Ben-Tuvia. - 1984. Mullidae. In: M. Dor, CLOFRES, Checklist of the Fishes of the Red Sea. Isr. Acad. Sci. Human., Jerusalem: 161-164.

Ehrlich, P.R. - 1986. Which animal will invade? In: H.A. Mooney and J.A. Drake (eds.), Ecology of Biological Invasion of North America and Hawaii. Ecol. Stud. No. 58 , pp. 79-95. SpringerVerlag, New York.

Golani, D. - 1990. Environmentally-induced meristic changes in Lessepsian fish migrants, a comparison of source and colonizing populations. Bull. Inst. oceanog. Monaco, no. special 7: 143-152.

Golani, D. - 1993. The sandy shore of the Red Sea - launching pad for Lessepsian (Suez Canal) migrant fish colonizers of the eastern Mediterranean. J.Biogeog., 20: 579-585.

Golani, D. - 1994. Niche separation between colonizing and indigenous goatfishes (Mullidae) of the Mediterranean coast of Israel. J. Fish Biol., 45: 503-513.

Gosline, W.A. - 1984. Structure, function and ecology in the goatfishes (family Mullidae). Pacif. Sci., 38: 312-323.

Gray, A.J. - 1986. Do invading species have definable genetic characteristics? Philosop. Trans. Roy. Soc. London. Ser. B 314: 655-674.

Harris, H. and D.A. Hopkinson. - 1976. Handbook of Enzymes Electrophoresis in Human Genetics. North Holland Pub. Co. Amsterdam.

Hedrick, F.W., M.E. Ginevan and K.P. Ewing. - 1976. Genetic polymorphism in heterogeneous environments. Ann. Rev. Ecol. System., 7: 1-32.

Holdgate, M.W. - 1986. Summary and conclusions: Characteristics and consequences of biological invasions. Philosop. Trans. Roy. Soc. London. Ser. B 314: 733-742.
Kühlmorgen-Hille, G. - 1974: Mullidae. In: Fischer, W. and P.J.P. Whitehead (eds.). FAO species indentification sheets for fishery purpose. Eastern Indian Ocean (fishing area 57) and Western Central Pacific (fishing area71). FAO United Nations, Rome.

Lavee, D. and U. Ritte. - 1994. Genetic variability and success in colonization in two intertidal mussels. In: A.R. Beaumont (ed.), Genetics and Evolution of Aquatic Organisms, pp. 168-176. Chapman and Hall.

Lee, C.K.C. - 1974. The reproduction, growth and survival of Upeneus moluccencus (Bleeker) in relation to the commerical fishing in Hong Kong. Hong Kong Fish. Bull., 4: 17-32.

Lozano Rey, L. - 1952. Peces fisoclistos, Subserie Toracicos. Prima parta. Mems. R. Acad. Cienc. Exact. Fis. Nat. Madr., ser.: Cien. Nat. 14. $378+$ XV pp.

Mamuris, Z., A.P. Apostolidis and C. Triantaphyllidis. - 1998. Genetic protein variation in red mullet (Mullus barbatus) and striped red mullet ( $M$. surmuletus) populations from the Mediterranean Sea. Mar. Biol., 130: 353-360.

Munro, J.L. - 1976. Aspects of the biology and ecology of Caribbean reef fishes: Mullidae (goat-fishes). J. Fish Biol., 9: 79-97.

Nei, M. - 1978. Estimation of average heterozygosity and genetic distance from a small number of individuals. Genetics, 89: 583-590.

Nevo, E., A. Beiles and R. Ben-Shlomo. - 1984. The evolutionary significance of genetic diversity. In: G.S. Mani (ed.), Ecological, demographic and life history correlates. Evol. Dynam. Gen. Diver. Lec. Notes Biomath., 53: 13-213.

Ota, T. - 1993. Genetic distance and phylogenetic analysis. The Pennsylvania State University. University Park, PA.

Papaconstantinou, C., N. Tsimenidis and Ch. Daoulas. - 1981. Age, growth and reproduction of red mullet (Mullus barbatus L., 1758) in the Gulf of Sronikos and Thermaikos. Thalessugraphica, 4 (1): 39-66.

Parsons, P.A. - 1984. Colonizing species: a probe into evolution via the organism. Endeavour, New Ser., 8(3): 108-112.

Ritte, U. and A. Pashtan. - 1982. Extrem levels of genetic variability in two Red Sea Cerithium species (Gastropoda: Cerithidae). Evolution, 36: 403-407.

Safriel, U.N. and U. Ritte. - 1980. Criteria for the identification of potential colonizers. Biol. J. Linn. Soc., 13: 287-297.

Saitou, N. and M. Nei. - 1987. The neighbour-joining method: a new method of reconstructing phylogenetic trees. Molec. Biol. Evol., 6: 539-545.

Selander, R.K., W.G. Hunt, S.Y., Yang, W.K., Johnson and J.B. Gentry. - 1971. Biochemical polymorphism and systematics in the genus Peromyscus. I. Variation in the old-field mouse (Peromyscus polionctus). Stud. Gen. VI. Univ. Texas Publ., 7103: 49-91.

Shaklee, J.B., C.S. Tamaru and R.S. Waples. - 1982. Speciation and evolution of marine fishes studies by the electrophoretic analysis of proteins. Pacif. Sci., 36: 141-157.

Sorden, C.T. - 1983. Feeding relationship of goatfishes in the Northwestern Hawaiian Islands. Sea Grant Quart. Univ. Hawaii, 5 (2): 1-6.

Stepien, C.A., J.E. Randall and R. Rosenblatt. - 1994. Genetic and morphological divergence of circumtropical complex of goatfishes: Mulloidichthys vanicolensis, M. dentalus and M. martinicus. Pacif. Sci., 48: 44-56.

Wahbeh, M.I. - 1992a. The food and feeding habits of the goatfishes, Mulloides flavolineatus and Mulloides vanicolensis in the Gulf of Aqaba, Jordan. Sencken. marit., 22(3/6): 245-254.

Wahbeh, M.I. - 1992b. Aspects of the reproduction and growth of two species of goatfishes (Mullidae) from Aqaba, Red Sea. Sancken. marit., 22(3/6): 255-264.

Waples, R. - 1987. A multispecies approach to the analysis of gene flow in marine shore fishes. Evolution 41: 385-400.

Williamson, M. and A. Fitter. - 1996. The characters of successful invaders. Biol. Conser. 78: 163-170.

Workman, P.L. and J.D. Niswander. - 1970. Population studies on south-western Indian tribes. II. Local genetic differentiation in the Papago. Am. J. Hum. Genet. 22: 24-29.

Scient. ed.: M. Harmelin-Vivien 